\title{
NPEPPS wt Allele
}

National Cancer Institute

\section{Source}

National Cancer Institute. NPEPPS wt Allele. NCI Thesaurus. Code C95860.

Human NPEPPS wild-type allele is located in the vicinity of $17 q 21$ and is approximately 41

$\mathrm{kb}$ in length. This allele, which encodes puromycin-sensitive aminopeptidase protein, is involved in the modulation of peptide catabolism. 